\title{
Osmophobia and Odour-triggered Headaches - Review of the Literature and Main Research Centres
}

\author{
Raimundo Pereira Silva-Néto ${ }^{1}$ and Adriana Almeida Soares²
}

1. Federal University of Piauí, Teresina, Brazil; 2. Center of Neurology and Headache of Piauí, Teresina, Brazil

DOI: https://doi.org/10.17925/ENR.2017.12.01.24

\begin{abstract}
$\mathrm{T}$ here is an important relationship between odours and primary headaches. Patients may present osmophobia during headaches and odours may trigger headache attacks. This review aimed to describe the studies on osmophobia, odour-triggered headache, the main researchers and their research centres. Publications on the relationship between odours and primary headaches were searched in 193 sovereign countries and 48 dependent territories in all continents. We consulted the PubMed database and used the descriptors: "osmophobia in [name of the country or territory]"; "odours and headache in [name of the country or territory]" and "smell and headache in [name of the country or territory]". A total of 254 articles were found, but only 31 articles were considered relevant and composed this review. Of the 31 articles, 90.3\% were cross-sectional studies, 6.5\% case reports and 3.2\% systematic reviews. All studies were performed on three continents: Europe (45.2\%), America (32.2\%) and Asia (22.6\%). For the purpose of this study, North America and South America have been classed as one continent. No research was developed in Africa or Australia. More than $50.0 \%$ of the studies were conducted in Italy and Brazil. Only five authors published $38.7 \%$ of the studies. Osmophobia during headache attacks was investigated in $67.7 \%$ of studies, and odour-triggered headache in 19.3\%. Studies on osmophobia and/or odour-triggered headache were carried out in several countries. They were useful in differentiating between migraine and tension-type headache. This could improve the accuracy of diagnosis of migraine compared to the current criteria.
\end{abstract}

\section{Keywords}

Osmophobia, triggers, odours, primary headaches, migraine

Disclosure: Raimundo Pereira Silva-Néto and Adriana Almeida Soares have nothing to declare in relation to this article. No funding was received for the publication of this article.

Compliance with Ethics: This study involves a review of the literature and did not involve any studies with human or animal subjects performed by any of the authors.

Authorship: All named authors meet the International Committee of Medical Journal Editors (ICMJE) criteria for authorship of this manuscript, take responsibility for the integrity of the work as a whole, and have given final approval to the version to be published.

Open Access: This article is published under the Creative Commons Attribution Noncommercial License which permits any non-commercial use, distribution, adaptation and reproduction provided the original author(s) and source are given appropriate credit.

Received: 21 February 2017

Accepted: 21 March 2017

Citation: European Neurological Review,

2017;12(1):24-7

Corresponding Author: Raimundo Pereira Silva-Néto, Federal University of Piauí, Avenida Frei Serafim,

2280, Centro, Teresina, PI 64001-020, Brazil.

E: neurocefaleia@terra.com.br
Several studies have demonstrated the relationship between odours and primary headaches..$^{1-31}$ Generally, we observed a severe intolerance to odours, pleasant or unpleasant, during headache attacks. ${ }^{2,4-8,10,11,13-30}$ However, a limited number of studies showed that odours may trigger headache attacks in some patients, particularly in migraineurs $1,3,6,79,24$ and occasionally in cluster headache patients. ${ }^{12,18}$ This intolerance to odours is known as osmophobia, and according to two studies that investigated osmophobia in secondary headaches, it occurred during headache attacks only in the primary headaches. ${ }^{32,33}$ There is no description of osmophobia in secondary headaches yet. Some migraine patients may have osmophobia in the pain-free period. ${ }^{2}$

Many researchers have confirmed that osmophobia is a symptom associated with migraine. $2,4-8,10,11,13-30$ Despite such research, osmophobia is still not part of the diagnostic criteria for migraine. ${ }^{34}$ In recent years, these studies were carried out in several countries. It is important to study the relationship between odours and primary headaches because they may improve the diagnostic accuracy of these headaches. ${ }^{2,3}$

The objective of this study was to review the research on osmophobia in primary headaches and/ or odours as a trigger of headache attacks that have been carried out worldwide. To date, there are no review articles on osmophobia, and to the best of our knowledge, this is the first article that reviews the publications on osmophobia and headache worldwide.

\section{Methods}

In this review, we researched the relationship between headaches and osmophobia in 193 sovereign countries and 48 dependent territories in all continents. For the purpose of this study, North America and South America have been classed as one continent. In Africa, America, Asia, Europe and Australia, the number of sovereign countries and dependent territories were, respectively: 54 and 4; 35 and 20; 47 and 3; 43 and 10; and 14 and 11.

We consulted the PubMed database and used the following combination of descriptors: "osmophobia in [name of the country or territory]"; "odours and headache in [name of the country or territory]" and "smell and headache in [name of the country or territory]". For the three descriptors we found, 52, 80 and 122 articles, respectively. 
Of the 254 articles found, we excluded those that appeared in more than one descriptor (60 articles) and those that did not have the purpose of researching the relationship between headache and odours (163 articles). After exclusions, 31 articles were considered relevant and composed this review. The origin of the article was defined by the nationality of the first author.

\section{Results}

Of the 31 articles, 90.3\% (28/31) were cross-sectional studies, 6.5\% (2/31) case reports and 3.2\% (1/31) systematic review. All studies were performed on three continents: Europe (45.2\%), America (32.2\%) and Asia (22.6\%). No research was developed in Africa or Australia (Table 1).

Research was conducted in many countries, but more than $50.0 \%$ (16/31) of the studies were conducted in Italy and Brazil. In relation to the researchers, we found that only five authors published $38.7 \%$ (12/31) of these studies (Table 2). The majority of studies investigated the presence of osmophobia. There were 13 comparative studies between migraine and other primary headaches or controls without headache, $2,3,5,8,13,1,1,17-20,22,28,31$ and 10 that evaluated only migraine patients. $4,6,7,71,1,5,16,24,26,29,30$ As for odour-triggered headache, there were six studies detected, two comparative studies between migraine and other primary headaches, ${ }^{1,3}$ two with migraine patients, ${ }^{7,24}$ and two case reports. ${ }^{9.12}$ However, there were six other studies where pathophysiological aspects of the association between odours and

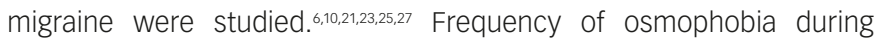
headache attacks in migraine patients ranged from 20.0-95.5\%. When studies compared patients with migraine, tension-type headache, and cluster headache, osmophobia predominated in migraine patients. Odour-triggered headache was also more prevalent in migraine patients and ranged from 34.7-90.2\% (Tables 2 and 3).

\section{Discussion}

While other studies on osmophobia or odour-triggered headache exist, for the purpose of this review we included only those that are indexed in PubMed. Since the 1980s, before the first classification of headache, ${ }^{35}$ odours were known to trigger migraine attacks and in the pain-free period, some patients remain symptomatic because they present an extreme intolerance to odours. ${ }^{36-38}$ While not having the purpose of researching the relationship between odours and headaches, many studies cited osmophobia as a manifestation associated with headache. ${ }^{39-41}$ We observed that Italy, Brazil and America conducted more research on odours and headaches. In addition, the five authors who have published most of these studies were born in these three countries. ${ }^{1-5,7,8,14,15,18-20}$ We do not have a scientific argument for this fact, but curiously these three countries were pioneers in the study of migraine.

In the 1940s, in America, Harold George Wolff (1898-1962) and John Ruskin Graham (1909-1980) found that ergotamine caused contraction of dilated blood vessels during migraine attacks.42-44 In the 1950s, the Brazilian neurologist Edgard Raffaelli Jr (1930-2006) began studies on headaches in Latin America. Currently, Brazilians are the second largest number of members of the International Headache Society, second only to the number of North Americans. ${ }^{45}$ In Italy, in the 1960s, Federigo Sicuteri (1920-2003) demonstrated the role of serotonin in the pathogenesis of migraine attack, therapeutic advances and pathophysiological knowledge. ${ }^{46}$

In this review, we found that relationship between odour and headaches, and osmophobia is common in both adult and paediatric patients with migraine; although, frequency data of osmophobia
Table 1: Distribution of 31 studies on osmophobia or odourtriggered headache according to continent

\begin{tabular}{|l|l|l|}
\hline Continents & \multicolumn{2}{l|}{ Studies } \\
\hline Europe & $n$ & $\%$ \\
\hline America* & 14 & 45.2 \\
\hline Asia & 10 & 32.2 \\
\hline Australia & 7 & 22.6 \\
\hline Africa & 0 & 0.0 \\
\hline
\end{tabular}

*For the purposes of this review, North America and South America have been classed as America.

and odour-triggered headache in migraine patients have been heterogeneous, ranging respectively from $20-86 \%$ and $34-70 \%$. The methodology used in each study is probably responsible for these variations. Some authors have suggested that osmophobia is very specific in the diagnosis of migraine..$^{22,40,41}$ It has low sensitivity, but high specificity in the differential diagnosis of migraine and tension-type headache, with higher values than the parameters for photophobia or phonophobia. ${ }^{8,13}$ In the International Classification of Headache Disorders, Second Edition (ICHD-2), osmophobia was cited in the appendix as a diagnostic criterion for migraine, ${ }^{47}$ but these data disappeared from the current classification (ICHD-3 $\beta)^{34}$ with no explanation. Despite evidences from the literature and constancy in the findings on osmophobia as a useful diagnostic marker, osmophobia is not included among the migraine diagnostic criteria in ICHD-3 $\beta$ (beta version). ${ }^{34}$

Migraine patients showed odour-triggered headache attacks even in low concentrations of the odour, and even with odours that are frequently well tolerated by the general population. Among the odours, perfume was the one that most commonly triggered headache, particularly those with floral scent. 1,13,14,19,26 The trigger mechanism of the headache by odours is still unknown. However, a study by functional magnetic resonance imaging (fMRI) during headache attacks in migraine patients and normal subjects showed increased activity of the limbic system and brainstem in response to olfactory stimulation only in migraine patients. This finding shows the strong relationship between the smell and the trigeminal nociceptive pathway in the pathophysiology of migraine. ${ }^{21}$ There is another hypothesis that the olfactory stimulus excites the locus coeruleus in migraine patients and causes noradrenaline release. Consequently, substance $\mathrm{P}$ and calcitonin gene-related peptide (CGRP) are released. These two potent and inflammatory vasodilator substances trigger the painful phenomenon. ${ }^{1,2}$ Recent studies have shown that inhalation of certain odours may cause severe headache attacks through stimulation of transient receptor potential ankyrin 1 (TRPA1), a nonselective cation channel expressed in sensory neurons, and activation of the trigeminovascular system. Consequently, there are nociceptive responses and calcium-dependent release of CGRP from trigeminal nerve terminals in the dura mater. Furthermore, TRPA1 activation may activate dural nociceptors and lead to central sensitization and cutaneous allodynia. ${ }^{48,49}$

Despite the fact that there have been many previous studies, there is presently no clinical marker for the diagnosis of migraine. Odour as trigger of headache could be a marker and a specific test to be used in patients with headache. In our recent research, we have used a perfume as a test to trigger headache. This test was positive only in migraine patients. ${ }^{3}$ 
Table 2: Characteristics of 31 studies published worldwide on osmophobia or odour-triggered headache, according to author and country

\begin{tabular}{|c|c|c|c|}
\hline Authors & $\begin{array}{l}\text { Country of } \\
\text { origin }\end{array}$ & $\begin{array}{l}\text { Number of } \\
\text { patients }\end{array}$ & Comments \\
\hline Silva-Néto et al., $2014^{1}$ & Brazil & 400 & $\begin{array}{l}\text { Comparative study between patients with migraine and TTH; odour-triggered headache only in migraineurs } \\
(70.0 \%)\end{array}$ \\
\hline Silva-Néto et al., $2014^{2}$ & Brazil & 400 & $\begin{array}{l}\text { Comparative study between patients with migraine and TTH; osmophobia predominated in migraineurs ( } 86.0 \% \\
\text { versus } 6.0 \%)\end{array}$ \\
\hline Silva-Néto et al., $2017^{3}$ & Brazil & 158 & $\begin{array}{l}\text { Experimental study between patients with migraine and other primary headaches; odour-triggered headache only } \\
\text { in migraineurs (34.7\%) }\end{array}$ \\
\hline $\begin{array}{l}\text { Rocha-Filho et al., } \\
2016^{4}\end{array}$ & Brazil & 147 & $\begin{array}{l}\text { A study with migraine patients; osmophobia predominated in migraineurs with anxiety and more years of } \\
\text { headache history }\end{array}$ \\
\hline $\begin{array}{l}\text { Rocha-Filho et al., } \\
2015^{5}\end{array}$ & Brazil & 235 & $\begin{array}{l}\text { Comparative study between migraine patients and TTH; osmophobia predominated in migraineurs (53.0\% versus } \\
11.5 \%), \text { especially in those with more years of headache history }\end{array}$ \\
\hline Fornazieri et al., $2016^{6}$ & Brazil & 113 & Cross-sectional study with migraineurs; osmophobia occured in 95.5\%; and odour-triggered headache in 90.2\% \\
\hline Kelman, $2004^{7}$ & USA & 1,237 & $\begin{array}{l}\text { A study with migraine patients; osmophobia and taste abnormality occurred in } 25 \% \text { of migraineurs and perfume } \\
\text { triggered migraine attacks in almost } 50 \% \text { of these patients }\end{array}$ \\
\hline Kelman, $2004^{8}$ & USA & 727 & $\begin{array}{l}\text { The study evaluated osmophobia and taste abnormalities in patients with headache and showed that these } \\
\text { symptoms are very specific in diagnosing migraine, but very insensitive }\end{array}$ \\
\hline $\begin{array}{l}\text { Roussos \& Hirsch, } \\
2014^{9}\end{array}$ & USA & 1 & $\begin{array}{l}\text { A 32-year-old woman with migraine had a headache attack triggered by garlic and onion aroma associated with } \\
\text { osmophobia }\end{array}$ \\
\hline Whiting et al., $2015^{10}$ & USA & 50 & $\begin{array}{l}\text { Comparative study between chronic migraine patients and controls showed that chronic migraine patients do not } \\
\text { appear to have a significant change in olfactory acuity during or between migraine attacks but they do appear to } \\
\text { be more likely to have abnormal olfactory acuity }\end{array}$ \\
\hline Baldacci et al., 201511 & Italy & 200 & A study of consecutive migraineurs; osmophobia during headache attacks was present in $58.0 \%$ of them \\
\hline Benemei et al., $2010^{12}$ & Italy & 1 & A 69-year-old man with cluster headache had a headache attack triggered by the scent given off by a tree \\
\hline Corletto et al., $2008^{13}$ & Italy & 275 & $\begin{array}{l}\text { Comparative study between migraine patients and TTH; osmophobia predominated in migraine patients ( } 25.1 \% \\
\text { versus } 8.3 \% \text { ) and had high specificity (92.0\%) in the differential diagnosis between migraine and TTH }\end{array}$ \\
\hline De Carlo et al., $2010^{14}$ & Italy & 1,020 & $\begin{array}{l}\text { Comparative study between migraine patients and TTH; osmophobia predominated in migraine patients ( } 34.6 \% \\
\text { versus } 14.3 \% \text { ) and when it was considered a diagnostic criterion, increased diagnostic accuracy of migraine }\end{array}$ \\
\hline De Carlo et al., $2012^{15}$ & Italy & 90 & $\begin{array}{l}\text { Study of diagnostic variation in young patients with TTH after 3-year follow-up; diagnostic rate of change was } \\
\text { significantly higher }(p=0.0002) \text { in cases with osmophobia }(62 \%)\end{array}$ \\
\hline Lovati et al., $2015^{16}$ & Italy & 673 & $\begin{array}{l}\text { Study showed that there was a significant association between osmophobia and cutaneous allodynia in chronic } \\
\text { migraine patients }\end{array}$ \\
\hline Raieli et al., $2005^{17}$ & Italy & 96 & $\begin{array}{l}\text { Frequency of osmophobia was evaluated in a young population with headaches; osmophobia was present only in } \\
\text { migraineurs (20.0\%) and absent in other forms of headache }\end{array}$ \\
\hline Zanchin et al., $2005^{18}$ & Italy & 775 & $\begin{array}{l}\text { Comparative study between migraine patients, TTH, cluster headache, and other headaches; osmophobia was } \\
\text { present in migraine (42.3\%), cluster headache }(6.8 \%) \text {, but absent in TTH and other headaches }\end{array}$ \\
\hline Zanchin et al., $2007^{19}$ & Italy & 1,005 & $\begin{array}{l}\text { Comparative study between migraine patients and TTH; osmophobia was present in patients with migraine with } \\
\text { and without aura, respectively, } 43.9 \% \text { and } 38.5 \% \text {, and in none with TTH }\end{array}$ \\
\hline Zanchin et al., $2016^{20}$ & Italy & 14,360 & $\begin{array}{l}\text { Systematic review compared migraine with TTH and showed predominance of osmophobia in migraineurs, both } \\
\text { adults and children; prevalence in adults was } 48.5 \% \text { versus } 8.9 \% \text {; and in children, } 23.4 \% \text { versus } 7.9 \%\end{array}$ \\
\hline $\begin{array}{l}\text { Stankewitz \& May, } \\
2011^{21}\end{array}$ & Germany & 40 & $\begin{array}{l}\text { Comparative study between migraine patients and controls; migraineurs during headache attack had changes in } \\
\text { neuronal processing in response to olfactory stimulation }\end{array}$ \\
\hline $\begin{array}{l}\text { Porta-Etessam et al., } \\
2009^{22}\end{array}$ & Spain & 68 & $\begin{array}{l}\text { Comparative study between migraine patients and TTH; osmophobia during headache attacks was present only in } \\
\text { patients with migraine, particularly in migraine without aura }\end{array}$ \\
\hline $\begin{array}{l}\text { Demarquay et al., } \\
2008^{23}\end{array}$ & France & 13 & $\begin{array}{l}\text { Comparative study between migraine patients and controls revealed that during olfactory stimulation, migraineurs } \\
\text { showed changes in regional cerebral blood flow }\end{array}$ \\
\hline Sjöstrand et al., $2010^{24}$ & Sweden & 60 & $\begin{array}{l}\text { Female migraine patients with headache attacks induced by odour were investigated; in } 63.3 \% \text { of patients, } \\
\text { headache was triggered by odours and in } 81.7 \% \text { osmophobia occurred during headache attacks }\end{array}$ \\
\hline Park et al., $2015^{25}$ & South Korea & 220 & $\begin{array}{l}\text { Sensory hypersensitivities were examined in migraine patients with suicidality; osmophobia was a critical factor } \\
\text { for suicidality }\end{array}$ \\
\hline Saisu et al., $2011^{26}$ & Japan & 110 & $\begin{array}{l}\text { An olfactory test conducted to evaluate the association between migraine and smell; osmophobia was found in } \\
63.0 \% \text { of patients }\end{array}$ \\
\hline Ishii et al., $2014^{27}$ & Japan & 210 & Investigation of gene polymorphisms involved in photophobia and osmophobia in migraineurs \\
\hline Wang et al., $2012^{28}$ & Taiwan & 2,883 & $\begin{array}{l}\text { Comparative study between migraine patients, TTH and cluster headache; osmophobia was prevalent in } \\
\text { migraineurs }\end{array}$ \\
\hline Akdal et al., $2015^{29}$ & Turkey & 871 & $\begin{array}{l}\text { A comparative study between migraine patients with both aura and without aura, according to the presence of } \\
\text { vertigo or vestibular symptoms; osmophobia was present in migraineurs without aura with vestibular symptoms } \\
\text { (46.8\% versus } 33.2 \% \text { ) and with vertigo ( } 52.4 \% \text { versus } 37.1 \%)\end{array}$ \\
\hline
\end{tabular}


Table 2: Cont.

\begin{tabular}{|l|l|l|l|}
\hline Authors & $\begin{array}{l}\text { Country of } \\
\text { origin }\end{array}$ & $\begin{array}{l}\text { Number of } \\
\text { patients }\end{array}$ & Comments \\
\hline Baykan et al., 2016 & Turkey & 5,323 & $\begin{array}{l}\text { A comparative study between migraine patients with and without allodynia; osmophobia predominated in } \\
\text { migraine patients with allodynia (48.9\% versus 35.1\%) }\end{array}$ \\
\hline $\begin{array}{l}\text { Kayabaşoglu et al., } \\
2016^{31}\end{array}$ & Turkey & 90 & $\begin{array}{l}\text { Comparative study between migraine patients and healthy people showed that the olfactory threshold is lower in } \\
\text { migraineurs with osmophobia }\end{array}$ \\
\hline
\end{tabular}

TTH = tension-type headache.

Table 3: Prevalence of osmophobia during headache attacks in comparative studies of patients with migraine, tensiontype headache and cluster headache

\begin{tabular}{|c|c|c|c|c|c|c|c|}
\hline \multirow[t]{2}{*}{ Authors } & \multicolumn{2}{|c|}{ Migraine } & \multicolumn{2}{|c|}{ TTH } & \multicolumn{2}{|c|}{$\mathrm{CH}$} & \multirow[t]{2}{*}{$p$-value } \\
\hline & $n$ & $\%$ & $n$ & $\%$ & $n$ & $\%$ & \\
\hline Silva-Néto et al., $2014^{2}$ & $172 / 200$ & 86.0 & $12 / 200$ & 6.0 & - & - & $<0.001$ \\
\hline Rocha-Filho et al., $2016^{4}$ & 78/147 & 53.1 & $10 / 87$ & 11.5 & - & - & $<0.001$ \\
\hline Corletto et al., $2008^{13}$ & $42 / 167$ & 25.1 & $9 / 108$ & 8.3 & - & - & $<0.05$ \\
\hline De Carlo et al., 2010 & $215 / 622$ & 34.6 & $47 / 328$ & 14.3 & - & - & $<0.001$ \\
\hline Zanchin et al., $2005^{18}$ & $241 / 569$ & 42.3 & 0/135 & 0.0 & $3 / 44$ & 6.8 & $<0.001$ \\
\hline Zanchin et al., 2007 ${ }^{19}$ & $347 / 807$ & 43.0 & 0/198 & 0.0 & - & - & $<0.001$ \\
\hline Porta-Etessam et al., $2009^{22}$ & $13 / 45$ & 28.9 & $0 / 23$ & 0.0 & - & - & $<0.001$ \\
\hline Wang et al., $2012^{28}$ & $1,125 / 1,809$ & 62.2 & $20 / 138$ & 14.5 & $45 / 144$ & 31.3 & $<0.001$ \\
\hline
\end{tabular}

$\mathrm{CH}=$ cluster headache; $\mathrm{TTH}=$ tension-type headache.

\section{Conclusions}

Studies on osmophobia and/or odour-triggered headache were carried out in several countries. They were useful in differentiating between migraine and tension-type headache. This could improve the accuracy of diagnosis of migraine compared to the current criteria. $\square$
1. Silva-Néto RP, Peres MF, Valença MM, Odorant substances that trigger headaches in migraine patients, Cephalalgia, that trigger headact

2. Silva-Néto RP, Peres MF, Valença MM, Accuracy of osmophobia in the differential diagnosis between migraine and tension-type headache, J Neurol Sci, 2014;339:118-22.

3. Silva-Néto RP, Rodrigues ÂB, Cavalcante DC, et al., May headache triggered by odors be regarded as a differentiating factor between migraine and other primary headache? Cephalalgia, 2017;37:20-8

4. Rocha-Filho PAS, Marques KS, Torres RCS, et al., Migraine osmophobia and, anxiety, Pain Med, 2016,17:776-80.

5. Rocha-Filho PAS, Marques KS, Torres RCS, et al., Osmophobia and headaches in primary care: prevalence, associated factors, and importance in diagnosing migraine, Headache, 2015,55:840-5.

6. Fornazieri MA, Neto AR, de Rezende Pinna F, et al., Olfactory symptoms reported by migraineurs with and without auras, Headache, 2016,56:1608-16.

7. Kelman $L$, The place of osmophobia and taste abnormalities in migraine classification: a tertiary care study of 1237 patients, Cephalalgia, 2004;24:940-6.

8. Kelman L, Osmophobia and taste abnormality in migraineurs: a tertiary care study. Headache, 2004;44:1019-23.

9. Roussos AP, Hirsch AR, Alliaceous migraines, Headache 2014;54:378-82.

10. Whiting AC, Marmura MJ, Hegarty SE, et al., Olfactory acuity in chronic migraine: a cross-sectional study, Headache, 2015;55:71-5.

11. Baldacci F, Lucchesi C, Ulivi M, et al., Clinical features associated with ictal osmophobia in migraine, Neurol SCi, 2015;36:43-6.

12. Benemei $S$, Appendino $G$, Geppetti P, Pleasant natural scent with unpleasant effects: cluster headache-like attacks triggered by Umbellularia californica, Cephalalgia, 2010;30:744-6.

13. Corletto $E$, Dal Zotto $L$, Resos et al., Osmophobia in juvenile primary headaches, Cephalalgia, 2008;28:825-31.

14. De Carlo D, Dal Zotto L, Perissinotto E, et al., Osmophobia in migraine classification: a multicentre study in juvenile patients, Cephalalgia, 2010;30:1486-94.

15. De Carlo D, Toldo I, Dal Zotto L, et al., Osmophobia as an early marker of migraine: a follow-up study in juvenile patients, Cephalalgia, 2012;32:401-6.

16. Lovati C, Giani L, Castoldi D, et al., Osmophobia in allodynic migraineurs: cause or consequence of central sensitization? Neurol Sci, 2015;36:145-7.

17. Raieli V, Pandolfi E, La Vecchia M, et al., The prevalence of allodynia, osmophobia and red ear syndrome in the juvenile headache: preliminary data, J Headache Pain, 2005;6:271-3.

18. Zanchin $G$, Dainese $F$, Mainardi $F$, et al., Osmophobia in primary headaches, J Headache Pain, 2005;6:213-5.

19. Zanchin $G$, Dainese $F$, Trucco M, et al., Osmophobia in migraine and tension-type headache and its clinical features in patients with migraine, Cephalalgia, 2007;27:1061-8.

20. Zanchin G, Fuccaro M, Battistella P, et al., A lost track in ICHD 3 beta: A comprehensive review on osmophobia, Cephalalgia, 2016; https://doi.org/10.1177/0333102416678390. [Epub ahead of print].

21. Stankewitz A, May A, Increased limbic and brainstem activity during migraine attacks following olfactory stimulation, Neurology, 2011;77:476-82.

22. Porta-Etessam J, Casanova I, García-Cobos R, et al, Osmophobia analysis in primary headache, Neurologia, 2009;24:315-7.

23. Demarquay G, Royet JP, Mick G, et al., Olfactory hypersensitivity in migraineurs: a H(2)(15)O-PET study, Cephalalgia, 2008;28:1069-80

24. Sjöstrand C, Savic I, Laudon-Meyer E, et al., Migraine and olfactory stimuli, Curr Pain Headache Rep, 2010;14:244-51.

25. Park SP, Seo JG, Lee WK, Osmophobia and allodynia are critica factors for suicidality in patients with migraine, $J$ Headache Pain, 2015;16:529.

26. Saisu A, Tatsumoto M, Hoshiyama E, et al., Evaluation of olfaction in patients with migraine using an odour stick identification test, Cephalalgia, 2011;31:1023-8.

27. Ishii M, Usami S, Hara H, et al., MAOA and TNF- $\beta$ gene polymorphisms are associated with photophobia but not osmophobia in patients with migraine, Acta Neurol Taiwan, 2014:23:40-8.

28. Wang YF Fuh $\mathrm{l}$, Chen SP, et al. Clinical correlates and diagnostic utility of osmophobia in migraine, Cephalalgia 2012:32:1180-8.

29. Akdal G, Baykan B, ErtaşM, et al., Population-based study of vestibular symptoms in migraineurs, Acta Otolaryngol, 2015;135:435-9.

30. Baykan B, Ekizoglu E, Karli N, et al., Characterization of migraineurs having allodynia: Results of a large populationbased study, Clin J Pain, 2016;32:631-5.

31. Kayabașog lu G, Altundag A, Kotan D, et al., Osmophobia and olfactory functions in patients with migraine, Eur Arch Otorhinolaryngol, 2017;274:817-21.

32. Zanchin G, Dainese F, Perin C, et al., Osmophobia in secondary headaches, J Headache Pain, 2006;7:252.

33. Viaro $F$, Maggioni $F$, Mampreso $E$, et al., Osmophobia in secondary headaches. In: Proceedings of 13 th Congress of the European Federation of Neurological Societies, 2009 Sep 12-15; Florence Italy Eur I Neurol, 2009:16:1107.

34. Headache Classification Subcommittee of the Internationa Headache Society, The International Classification of Headache Disorders, 3rd edition (version beta), Cephalalgia, 2013;33:629-808

35. Headache Classification Subcommittee of the Internationa Headache Society, The International Classification of Headache Disorders, 1st edition, Cephalalgia, 1988;8:10-96.

36. Ardila A, Sanchez E, Neuropsychologic symptoms in the migraine syndrome, Cephalalgia, 1988:8:67-70.

37. Raffaelli Jr E, Martins OJ, D'água Filho AS, A role for anticonvulsants in migraine, Funct Neurol, 1986;1:495-8.

38. Blau JN, Solomon F, Smell and other sensory disturbances in migraine, I Neurol, 1985;232:275-6.

39. Morillo LE, Alarcon F, Aranaga N, et al., Clinical characteristics and patterns of medication use of migraineurs in Latin America from 12 cities in 6 countries, Headache, 2005:45:118-26.

40. Chou CH, Chao AC, Lu SR, et al., Cephalic venous congestion aggravates only migraine-type headaches, Cephalalgia, 2004;24:973-9.

41. Merikangas KR, Dartigues JF, Whitaker A, et al., Diagnostic criteria for migraine. A validity study, Neurology, 1994;44:11-6.

42. Robertson $\mathrm{S}$, Goodell $\mathrm{H}$, Wolff $\mathrm{HG}$, Headache; the teeth as a source of headache and other pain, Arch Neurol Psychiatry, 1947; $57: 277-91$

43. Wolff $\mathrm{HG}$, Headache mechanisms, McGill Med J, 1946:15:127-69.

44. Kunkle EC, Ray BS, Wolff HG, Studies on headache: the mechanisms and significance of the headache associated with brain tumor Bull N Y Acad Med, 1942:18:400-22.

45. Silva-Néto RP, The study of headache in the 1950s in Latin America by Edgard Raffaelli Júnior (1930-2006), Headache, 2015;55:713-7.

46. Fanciullacci M, Lance J, In memory of Federigo Sicuteri, a headache medicine pioneer, Cephalalgia, 2004;24:1090-1.

7. Headache Classification Subcommittee of the International Headache Society, The International Classification of Headache Disorders, 2nd edition, Cephalalgia, 2004;24:8-160.

48. Edelmayer RM, Le LN, Yan J, et al., Activation of TRPA1 on dural afferents: A potential mechanism of headache pain, Pain , 2012;153:1949-58.

49. Nassini R, Materazzi S, Vriens J, et al., The 'headache tree' via umbellulone and TRPA1 activates the trigeminovascular system, Brain, 2012;135:376-90. 